\title{
Autistic Disorders - Was Endocrine Involvement Forecasted?
}

\author{
Dr.med Benedikt Gasser* \\ Faculty of Medicine, University of Bern, Switzerland, Europe
}

Submission: May 15, 2018; Published: May 23, 2018

*Corresponding author: Med Benedikt Gasser, Faculty of medicine, University of Bern, Mittelstrasse 433012 Bern Switzerland, Tel: +41316315675

; Email: Benedikt.gasser@yahoo.com

Abstract

In his original analysis in 1944 Hans Asperger [1] described four cases of Fritz, Ernst, Harro and Hellmuth. In some of the cases hints can be found that an involvement of Hypothalamus-Pituitary system respectively steroid hormones is present in line with newer findings of involvement of steroid hormones in autistic disorders. However, despite hints from different side awareness of the potential involvement of the endocrine system seems to be generally sparse. Some recent studies elucidated some aspects of the endocrine system and its involvement in autistic disorders, whereby when combining this new evidence labor tests based on steroid hormones might be a valid opportunity to support the clinician in finding the proper diagnosis.

Keywords: Phenotype; Autism; Steroid Hormones; Cholesterol

\section{Introduction}

Asperger Syndrome is nowadays taxed as mild form of autistic disorders and was recently excluded in DSM-5 and is now subsumed under Autistic disorders, but still present as diagnosis by clinicians. [2], Hans Asperger [1] described in his original description four cases of Fritz, Ernst, Harro and Hellmuth. Principally, an involvement of endocrine system on different levels Hypothalamus-Pituitary axis, insulin metabolism, Cholesterol and especially steroid hormones was suggested [312]. Interestingly, Schwarz et al. 2011 showed an involvement of the Insulin-Growth Hormone and Chemokine \& Cytokine system, which would be in line with the described case of Harro. Having a detailed view, some endocrine involvement seems to be detectable in Hans Asperger's analysis. Especially the fourth case is impressive concerning an endocrine involvement. Forecasted Hans Asperger in a promising way an opportunity to improve clinical diagnosis by analyzing endocrine patterns?

\section{Reference to the Original Work}

With high probability, in some of the cases an endocrine involvement was described by Hans Asperger [1]. Especially a deregulation of the androgen homeostasis is to presume for the case of the boy Harro. He was small in stature, a thick central body, with stocky posture and strong musculature. The somatotype is described as disorganized e.g. short extremities, which could be in line with an involvement of Growth Hormone Homeostasis. Concerning the family it is interestingly mentioned that some nervous trait are present, which could be in line with a deregulation of ACTH-CRH Cortisol homeostasis. For another case Ernst a deregulation of Vagotonus was described in line with a deregulation of vegetative nerve system and an endocrine involvement. The most impressive case concerning endocrine involvement is Hellmuth, a child of parents without abnormalities. Interestingly, the mother of Hellmuth was 41 years old and during gestation having a heavy perinatal asphyxia. Shortly after gestation he had an epileptic seizure. The development was slow. During the whole development he was fat despite diet controlled by medical doctors only small hunger was reported. However, Hellmuth was gaining more and more weight developing obesity. With eleven years he came to the clinic whereby during examination fat breasts were imposing, whereby this state was not changing during more than six year period of clinical observation and hormonal treatment.

A two-sided maldescencus testis (cryptorchism) was treated with thyroid hormones and pituitary hormones, without having effects on the clinical outcome. Furthermore, bones seemed to hardly exist and interestingly joints could be overstretched easily. Further clinical signs were Genua valga and an overproduction of saliva, with hearing the saliva bubbles when speaking. The described case is in line with a general deregulation of the endocrine system on all levels (mineralocorticoid, glucocorticoid, androgens). The strong dysfunction of the parasympathetic nerve influenced saliva and would be in line with an impairment of vegetative nerve system with including 
deregulation of Hypothalamus-Pituitary system. Furthermore, also an involvement of Calcium metabolism (Parathormone / Vitamin - D) is likely to suggest. More often boys are affected and furthermore, hyposexuality was mentioned as part of the autistic traits in line with alterations of androgen homeostasis. Furthermore, the autistic traits as described by Hans Asperger seem to persist during the whole live implying alterations on DNA respectively chromosome level and consequently probably persisting during the whole life span.

\section{Discussion \& Practical Implications}

To sum up, for the case of Hellmuth a very strong evidence for an involvement of endocrine system was described making it necessary to observe the cases of Fritz, Ernst \& Harro once again. Generally, such strong a line of argument and stringency as for Hellmuth cannot be found for the three other cases. And for Fritz it was directly mentioned in the original work by Hans Asperger [1] that no involvement can be found. However, this statement was only based on the clinical examination and not on further labor tests such as analyzing blood or urine, which hardly existed or not as developed as today. An involvement in 1944 of the Hypothalamus-pituitary Gland System can be supposed and for example when going back to the parents of children one mother was described as very nervous in line with an involvement of CRH-ACTHergic respectively Cortisol homeostasis. Trying to decipher general recommendations it can be mentioned that for example no specific labor tests exist for detecting autistic disorders or Asperger syndrome, although involvement of inflammation markers such as Chemokines and Cytokines exist [11]. Genom-wide screenings are part of a relatively encompassing diagnostic [13]. An easy applicable standardization does not seem to were described, whereby based on newer findings analyses of steroid hormones might be a good possibility in order to secure a clinically examined diagnosis.

\section{References}

1. Asperger H (1944) Die Autistischen Psychopathen im Kindesalter Archiv fur Psychiatrie und Nervenkrankheiten 117: 76-136.
2. Ariella Ritvo R, Ritvo ER, Guthrie D, Ritvo MJ (2008) Clinical evidence that Asperger's disorder is a mild form of autism. Compr Psychiatry 49(1): 1-5.

3. Baron Cohen S, Auyeung B, Norgaard Pedersen B, DM Hougaard, MW Abdallah, et al. (2015) Elevated fetal steroidogenic activity in autism. Molecular Psychiatry 20(3): 369-376.

4. Chakrabarti B, Dudbridge F, Kent L, Wheelwright S, Hill Cawthorne G, et al. (2009) Genes related to sex steroids, neural growth, and socialemotional behavior are associated with autistic traits, empathy, and Asperger syndrome. Autism Res 2(3): 157-77.

5. Curin JM, Terzic J, Petkovic ZB, Zekan L, Terzic IM, et al. (2003) Lower cortisol and higher ACTH levels in individuals with autism. J Autism Dev Disord 33(4): 443-448.

6. Dziobek I, Gold SM, Wolf OT, Convit A (2007) Hypercholesterolemia in Asperger syndrome: independence from lifestyle, obsessivecompulsive behavior, and social anxiety. Psychiatry Res 149(1-3): 321324.

7. Gorinaa AS, Kolesnichenkob LS, Mikhnovichc VI (2011) Catecholamine Metabolism in Children with Asperger's and Kanner's Syndromes. Biomedical Chemistry 5(4): 397-401.

8. Hamza RT, Hewedi DH, Ismail MA (2010) Basal and Adrenocorticotropic Hormone Stimulated Plasma Cortisol Levels Among Egyptian Autistic Children: Relation to Disease Severity. Ital J Pediatr 36: 71.

9. Iwata K, Matsuzaki H, Miyachi T, Shimmura C, Suda S, et al. (2011) Investigation of the serum levels of anterior pituitary hormones in male children with autism. Molecular Autism 2: 16.

10. Marinovic Curin J, Marinovic Terzic I, Bujas Petkovic Z, Zekan L, Skrabic $\mathrm{V}$, et al. (2005) Slower cortisol response during ACTH stimulation test in autistic children. Eur Child Adolesc Psychiatry 17(1): 39-43.

11. Schwarz E, Guest PC, Rahmoune H, Wang L, Levin Y, et al. (2011) Sexspecific serum biomarker patterns in adults with Asperger's syndrome. (12): $1213-1220$

12. de Quervain DJ, Aerni A, Schelling G, Roozendaal B (2009) Glucocorticoids and the regulation of memory in health and disease .Front Neuroendocrinol 30(3): 358-370.

13. Auranen M, Vanhala R, Varilo T, Ayers K, Kempas E, et al. (2002) A genomewide screen for autism-spectrum disorders: evidence for a major susceptibility locus on chromosome 3q25-27. Am J Hum Genet 71(4): 777-790.

\section{Your next submission with Juniper Publishers} will reach you the below assets

- Quality Editorial service

- Swift Peer Review

- Reprints availability

- E-prints Service

- Manuscript Podcast for convenient understanding

- Global attainment for your research

- Manuscript accessibility in different formats

( Pdf, E-pub, Full Text, Audio)

- Unceasing customer service

Track the below URL for one-step submission https://juniperpublishers.com/online-submission.php 